\title{
Diversity Climate of Respect and the Impact on Faculty Extra Role Behaviors
}

\author{
Monica C. Gavino \\ San Jose State University
}

\author{
Jason Lambert \\ Texas Woman's University
}

Ekundayo Akinlade

University of Wisconsin Parkside

\begin{abstract}
The aim of this study is to examine how faculty perceptions of the diversity climate affect faculty extra role behaviors and subsequently students' satisfaction with their academic performance. The results indicate that the diversity climate of respect among faculty is positively related to their extra effort and going above and beyond for students. As well, that the effects of both student perceptions of the diversity climate of respect and student perceptions of faculty extra role behaviors on their satisfaction with academic performance are not only significant but connected. We also investigate the moderating effect of student race on that relationship. This study finds that student race and ethnicity play a role on how the diversity climate of respect affects their satisfaction with their academic performance.
\end{abstract}

Keywords: climate of respect, faculty extra role behaviors, satisfaction with academic performance

\section{INTRODUCTION}

Given the demographic changes of the population in the U.S., the proportion of racial and ethnic minorities attending public and private non-profit four-year colleges and universities continues to increase substantially (Fry \& Cilluffo, 2019). According to the 2019 NCES (National Center for Education Statistic) report between 2000 and 2016, college enrollment rates increased by 17\% for Latinx students, and 5\% for Black students, while the increase for White students was 3\% (de Brey, et al., 2019). Proactively promoting a climate in which diverse students of all backgrounds feel respected and can excel is indispensable for educational institutions (Bowman \& Denson, 2014; Schachner et al., 2019). Research conducted on institutions of higher education consistently finds that student perceptions of the diversity climate are indeed associated with important outcomes such as college adjustment, sense of belonging, satisfaction, grades, and persistence (e.g., Bowman \& Denson, 2014; Fischer, 2007; Locks et al., 2008; Nora \& Cabrera, 1996). These outcomes lead to degree completion which is one major reason this is such an important area of study. Moreover, research on diversity climate from a faculty perspective is somewhat scant, particularly in higher education, as the focus has been predominantly on the experiences of students. The research conducted on minority faculty finds disparities in recruitment, lack of support of faculty of color, and subtle biases within institutions (Piercy et al., 2005). Minority faculty also report feeling isolated and discouraged, 
experiencing offensive humor (by colleagues) and racial micro-aggressions, and having concerns with institutional hiring practices (Bennett et al., 2011). What is not evident in the literature is the link between faculty perceptions of the diversity climate and the effect on student outcomes. To date, few studies have examined the impact of diversity climate on faculty performance, and none, to our knowledge, have investigated the impact that the climate of respect has on extra-role behaviors of faculty, more specifically, going above and beyond for students.

We draw from the organizational literature on employee perceptions of the extent to which an organization values and respects differences through their diversity-related policies, practices, and procedures (Kossek \& Zonia, 1993; Lauring \& Selmer, 2011; Pugh et al., 2008; Singh et al., 2013). This research has demonstrated that a pro-diversity climate can enhance employee performance and organizational outcomes (Foster \& Harris, 2005; Gonzales \& DeNisi, 2009; Kearney \& Gebert, 2009; McKay et al., 2007; Mor Barak et al., 1998; Nishii, 2013; Wrench, 2005) such as, reduced turnover, improved corporate image, greater creativity and problem-solving, increased market share and, most relevant to this study, extra-effort behavior or organizational citizenship behavior (Cox, 1994; DiPaola \& Hoy, 2005; Joshi et al., 2006; Köllen, 2016; Kundu \& Mor, 2016; Moon, 2016; Sacco \& Schmitt, 2005; Triana et al., 2015). Therefore, we consider faculty as employees of the institution and in Study 1 examine their perceptions of the climate of respect and the effect on their extra role behaviors. In Study 2, we investigate the effect of faculty extra role behaviors on student satisfaction with their academic performance. This line of research is relevant for student outcomes, in light of evidence from the business setting suggesting that employees from underrepresented groups (e.g., minorities and women) often feel marginalized, excluded or discriminated against (Lauring \& Selmer, 2011; Moeller et al., 2010), thereby limiting their motivation and ability to contribute to their organizational goals (Blank \& Slipp, 1994; Goldman et al., 2006; Mc Kay, et al., 2008; Roberson \& Block, 2001).

We build on this work by integrating it with diversity climate research conducted in academic settings to better understand the relationship between diversity climate, faculty extra role behaviors and student outcomes. We examine faculty extra role behaviors given that generally faculty are not closely monitored or supervised in the traditional sense and going above and beyond their role is especially important in academic contexts (George \& Jones, 1997; LePine et al., 2000). Extra role behaviors are defined as positive and discretionary behaviors that are 1) not specified in advance by role prescriptions, 2) not recognized by formal reward systems, and 3) not a source of punitive consequences when not performed by job incumbent (Van Dyne \& LePine, 1998). Studies suggest that students who perceive their faculty members to be caring and have positive informal interactions with them report higher satisfaction with college and enhanced intellectual and personal development (Lamport, 1993). We are interested in assessing the role of the climate of respect and its impact on faculty extra role behaviors and their propensity to go above and beyond one's specific job duties to influence student outcomes. We focus on climate of respect, because existing literature consistently ranks respect as one of the most important, valuable and desirable work values (Van Quaquebeke et al., 2009; Robotham \& Cortina, 2019). In their recent study, Robotham and Cortina (2019) study generalized respect as equitable treatment of all employees, and they found that climate of respect predicts harassment based on sex and ethnicity above and beyond the effects of climate for harassment. In the second study, we test our model with students' satisfaction with their academic performance as a student outcome, given the far-reaching consequences of high student satisfaction including increased motivation for learning, higher self-efficacy, deeper cognitive learning, and ultimately yielding better academic achievement (Baturay, 2011; Cole et al., 2014; Kim \& Lee, 2015; Lin et al., 2019; Portolese \& Trumpy, 2014; Shakurnia et al., 2014). To advance our understanding of the implications of these relationships to diverse racial groups, we further examine the moderating role of student race and ethnicity on student satisfaction with academic performance.

We hope to make several contributions to the literature. First, our research extends the diversity climate literature by examining the dual effect of climate of respect on both faculty and students. While diversity climate on campuses has been studied in institutions of higher education, this has occurred predominantly through the lens of students. By focusing on both student and faculty perceptions of the diversity climate, this allows us to capture more fully the impact of campus diversity climate on student outcomes. Second, 
by focusing on faculty extra role behaviors, this study not only examines the relationship between faculty perceptions of the diversity climate on faculty extra role behaviors, but also examines how this discretionary effort contributes to student outcomes. Scholars who study contextual performance and workplace diversity contend that employees who perceive a positive diversity climate are more willing to exert extra effort (Chung et al., 2015; Podsakoff et al, 2000), yet few studies have investigated these relationships in the context of higher education. We extend this literature by not only examining the effect of climate of respect on faculty extra role behaviors, but also how these two variables affect student satisfaction with academic performance.

Finally, by investigating the role of student race and ethnicity as a moderator, our study contributes to the broader literature on diversity. Research has shown that diverse student groups view the campus diversity climate differently (Cabrera et al., 1999; Hurtado et al., 2015; Hurtado \& Carter, 1997; Hurtado \& Alvarado, 2012; Nguyen et al., 2018). The current study sharpens our understanding of the role race plays, by suggesting that the effect of diversity climate of respect on student satisfaction with their academic performance varies as a function of race.

\section{LITERATURE REVIEW AND HYPOTHESES}

\section{Diversity Climate}

Organizational diversity climate is an emerging area of scholarly research that focuses on individual perceptions of the extent to which an organization provides all employees with equal opportunity to succeed and values their contributions. Diversity climate can be viewed as part of a sense-making process, leading to shared meaning of 'the way things are around here' regarding an organization's commitment to maintaining diversity and eliminating discrimination in the workplace (Lauring \& Selmer, 2011). According to Cox's (1994) interactional model of cultural diversity, employee perceptions of organizational diversity climate play a significant role in shaping their affective and behavioral outcomes (Chung et al., 2015; Singh \& Selvarajan, 2013). Positive organizational contexts such as a supportive diversity climate foster a socially integrated workforce (Singh \& Selvarajan, 2013), and encourage employees to become more emotionally attached to the organization (Chung et al., 2015; Gonzalez \& DeNisi, 2009; McKay et $a l ., 2007)$. These attitudes will likely induce employees with greater commitment to their jobs and promote their work motivation, which should increase their willingness to engage in tasks that go beyond the call of duty (Chung et al., 2015; Podsakoff et al., 2000). Prior research from business settings supports this contention. For example, Gonzalez and DeNisi (2009) found that organizational support for diversity is associated with extra effort or discretionary behavior.

The limited evidence from recent studies in academic settings indicates that faculty perceptions of diversity climate will likely promote faculty performance including citizenship behavior. For example, Lauring and Selmer (2011) found that the diversity climate was positively related to group performance in an academic department. Bennett and colleagues (2011) report that the faculty experience of the campus diversity climate played a significant role in their ability to support, advocate, and be present for Black and Latinx/Hispanic students. In yet another study, Milem (2001) indicates that fair treatment of faculty of color and women predicted civic responsibility and student centeredness.

Furthermore, consistent with the extant literature, we contend that faculty, as employees of institutions where they are treated with respect and dignity, are more likely to go above and beyond their stipulated job requirements. Previous research suggests that "employees' courteous, respectful and caring behavior", fosters positive behaviors such as organizational citizenship behavior (Erum et al., 2020; p.359)]. As a result, we contend that diversity climate, specifically climate of respect, will have an impact on the extra role behaviors of faculty in an academic setting.

\section{Faculty Extra-Role Behaviors}

Researchers have long recognized that successful organizations rely on employees who go above and beyond their formal job responsibilities (e.g., Katz 1964). This discretionary effort has been studied under different labels such as extra-role performance, organizational citizenship behavior, and contextual 
performance. Teaching is by nature a complex activity requiring professional judgments, and as such cannot be adequately prescribed in job descriptions or contracts, therefore, faculty extra role behaviors is an especially important aspect of the performance of faculty in academic settings (DiPaola \& Hoy, 2005). DiPaola and Hoy (2005) did find a significant relationship between student achievement and the level of faculty organizational citizenship behavior in a high school setting.

As noted by several researchers, carrying out core job tasks is necessary but not sufficient for job effectiveness in academic settings. Faculty are primarily responsible for the classroom experience of their students, so it follows that the extent to which faculty go above and beyond their prescribed role will influence student perceptions of their educational experience, including satisfaction with their academic performance. Indeed, this assertion is further supported by research conducted in service industries, where extra effort and organizational citizenship behaviors have been linked to client satisfaction. In fact, in their meta-analysis, Podsakoff and colleagues (2009) showed that organizational units characterized by high levels of organizational citizenship behaviors had more satisfied customers. While we are not suggesting that students are clients per se, we are illustrating the important impact of extra role behaviors in nonacademic settings.

Faculty who exert extra effort, for example, voluntarily go above and beyond their prescribed role, engage in behaviors such as working with students outside of the classroom or beyond office hours to ensure their success, mentor students about career goals and opportunities, and spend time on innovative course material/activities that will help prepare students for the workplace (DiPaola \& Hoy, 2005) and therefore achieve the mission and goals of the institution. Such behaviors are likely to lead to higher student performance thereby improving student satisfaction with their academic performance. Faculty extra role behaviors is, therefore, expected to promote student satisfaction with their academic performance (Jimmieson et al., 2010). While discretionary effort has been researched extensively in business settings and yielded important insights, research examining the effect of faculty extra role behaviors on student outcomes is sparse as few studies have been conducted in academic settings (DiPaola \& Tschannen-Moran, 2001). Students in settings that benefit from high faculty extra role behaviors are likely to experience even greater satisfaction with their academic performance than those in settings with low faculty extra role behaviors. Diversity climate and the demographic make-up of students play important roles in students' satisfaction with their academic performance. However, we contend that faculty extra role behaviors are understudied factors that are equally important and should have a positive effect on students' satisfaction with their academic performance. Indeed, Reid and Radhakrishnan (2003) found that students' overall satisfaction with their university was most related to academic concerns.

Hypothesis 1: Climate of respect is positively related to faculty-reported extra role behaviors and going above and beyond for students.

\section{Campus Climate}

According to Hurtado and colleagues (2012), campus climate for diversity can be conceptualized as a product of four elements: (1) historical legacy of inclusion and exclusion of various racial/ethnic groups; (2) structural diversity in terms of numerical representation of various racial/ethnic groups; (3) the psychological climate of perceptions and attitudes between and among groups; and (4) the behavioral climate dimension, characterized by intergroup relations on campus. They posit that these dimensions are all connected and influence each other. In this study, we focus on the psychological dimension. As noted, research indicates that students perceive the campus climate as a function of their race, with students of color reporting more prejudice, discrimination, and racist campus environments (Hurtado et al, 1998; 2012; 2015; Harper \& Hurtado, 2007; Nguyen, et al., 2018). For example, Loo and Rolison (1986) found that while 68 percent of White students perceived their university as supportive of minority students, only 28 percent of the African American and Latinx students reported similar support. Similarly, Cabrera and Nora (1994) found that while students of color were more sensitive to different forms of prejudice and discrimination, White students were less likely to perceive such nuances. 
As such, these perceptions of the campus climate are important as they can have real consequences for both minority and majority student outcomes. In one longitudinal study, Latinx student perceptions of racial tension between groups on campus in their first year had a consistently negative effect on their academic and psychological adjustment in subsequent college years (Hurtado et al., 1996; 1998). In another study at a university perceived as having a high level of alienation, there was less satisfaction and more social alienation among African American and Asian American students (Bennett \& Okinaka, 1990). That said, several studies indicate that White students are also affected by the climate for racial/ethnic diversity. Nora and Cabrera (1996) report that White student persistence in college was both directly and indirectly influenced by perceptions of discrimination. Of significance to the present study is research that suggests that climate for diversity is linked to student satisfaction. In their 1998 study, Hurtado and colleagues found that students attending desegregated institutions with more campus racial diversity were more likely to express greater satisfaction. Because students who perceive supportive diversity campus climates are more likely to feel valued and supported by the institution, feeling supported through the extra role behaviors of faculty should also be more salient, and thus promote higher student satisfaction with academic performance. We contend that when students perceive respect for their identity in the university setting, their positive experiences are not only influenced by the university's climate, but also by the faculty extra role behaviors which are also influenced by the university's climate.

\section{Student Race and Ethnicity}

Diversity climate is important to all individuals (Hicks-Clarke \& Iles, 2000; McKay et al., 2007) because everyone, irrespective of the identity group they belong to, wants to be valued and treated fairly. However, theory and research suggest that differences in organizational experiences are apt to make it more significant to members of certain identity groups (McKay et al., 2011). According to social identity theory (SIT; Stryker, 1968; Tajfel \& Turner, 1986), people categorize themselves into social groups based upon salient characteristics such as race, ethnicity, sex, age, and national origin, and attach meaning to membership in these identity groups (McKay et al., 2011). Furthermore, our perception of the social context is shaped by our group membership (Alderfer, 1987). Consequently, perceptions of diversity-related policies and practices that indicate the extent to which the organization values different identity groups, will be affected by identity group membership. Existing research suggests that in business contexts (McKay et al., 2007; 2008) as well as academic settings (e.g., Loo \& Rolison, 1986; Hurtado et al., 1996; Nora \& Cabrera, 1996), diversity climate perceptions vary based on racial identity groups (Kossek \& Zonia, 1993; McKay et al., 2007; Singh \& Selvarajan, 2013). Organizations with work climates perceived to value diversity are more attractive to women and minorities compared to organizations that do not explicitly promote diversity practices (Avery, 2003; Brown et al., 2006; Lambert, 2015; Perkins et al., 2000).

We, therefore, examine the effect of the climate of respect on faculty extra role behaviors and going above and beyond for students and satisfaction with academic performance. In our first study, we test the relationship between faculty reported climate of respect and their faculty extra role behaviors and going above and beyond for students. We then confirm the relationship in Study 2 and contend that climate of respect and faculty extra role behaviors impact student satisfaction with their academic performance. Finally, we propose that this relationship will differ based on group membership.

Hypothesis 2: Climate of respect is positively related to students' satisfaction with their academic performance.

Hypothesis 3: Faculty extra role behaviors is positively related to students' satisfaction with their academic performance.

Hypothesis 4: Climate of respect affects students' satisfaction with academic performance both directly and indirectly through faculty extra-role behaviors. 
Hypothesis 5: The effect of climate of respect on students' satisfaction with academic performance differs for minority students compared to non-Hispanic White students, such that the effect of climate of respect on student satisfaction with academic performance will be more salient for minority students.

\section{METHODOLOGY}

\section{Sample and Procedures}

Quantitative data for this study was collected from a private university in the Midwest region of the U.S.A. as part of a broad university wide survey administered online. In Study 1, faculty were invited to participate in a faculty survey and the data were used to test Hypothesis 1. In Study 2, students were invited to participate in a student survey and the data were used to test Hypotheses 2-5.

\section{Study 1}

Participants. Faculty were invited to participate in a voluntary and anonymous faculty online survey. In total 159 faculty responded to the survey. This represented a participation rate of $85 \%$ for faculty. Respondents who answered the demographic questions identified as $64.4 \%$ female and $31.5 \%$ male; $72 \%$ were non-Hispanic White; 3.42\% Latinx/Hispanic; 2.74\% Black/African American; 2.74\% MiddleEastern; 2.0\% Asian; and less than 1 percent Native America/American Indian; 7.5\% were younger than $35 ; 16.4 \%$ between $35-44 ; 18.59 \%$ between $45-54 ; 28.7 \%$ between $55-64 ; 13.7 \%$ between $65-74$ years old; and less than $1 \%$ were older than 75 . Subjects with missing data related to the variables being investigated were not included in the statistical analysis. As a result, 147 valid responses for faculty $(\mathrm{N}=147)$ were used.

\section{Measures}

The survey questions utilized were adapted from questions and sources provided by Excelencia in Education's Latino Student Success (LSS) Inquiry Model (2014); which included surveys utilized by member institutions from which to draw questions.

Climate of Respect. Seven items were used to measure climate of respect for identity affiliation for faculty yielding a coefficient $\alpha=0.90$. Sample items include: "I am treated with respect and dignity regardless of my gender," and "I am treated with respect and dignity regardless of my race or ethnicity." Faculty responded to all questions on a 7 -point scale $(1=$ strongly disagree to $7=$ strongly agree $)$.

Faculty Extra Role Behaviors. In general, researchers conceive of organizational citizenship behavior (OCB) as comprising several dimensions, although debate still exists as to the number and nature of these dimensions (LePine, Erez, \& Johnson, 2002). Scholars argue that in academic settings, because OCBs directed towards individuals also benefit the institution, all aspects of OCB can be captured by a single construct (DiPaola \& Tschannen-Moran, 2001). Furthermore, and germane to our study, previous studies have found single-item measures to be acceptable when the measured constructs are not complex or difficult (Reichers \& Hudy, 1997). Therefore, in our study faculty extra role behaviors refers to faculty going above and beyond their officially prescribed role. As such, faculty reported faculty extra role behaviors was measured with the following question: "Faculty are willing to put in a great deal of effort beyond what is normally expected in order for our students to be successful". In order to mitigate inflated self-reporting faculty extra role behaviors by faculty, the item was phrased so that respondents answered the questions about the faculty body as whole versus themselves. Faculty responded to this question on a 7-point scale (1 $=$ strongly disagree to $7=$ strongly agree).

Control Variables. Race and ethnicity, age and gender were entered as control variables for the faculty sample consistent with prior studies on diversity (e.g., Avery, 2003; Thomas \& Wise, 1999; Walker et al., 2009). Age was entered as a continuous variable (participants selected age ranges represented by values with a range of $1=$ younger than 35 to $6=75$ and older). Tenure was also entered as a continuous variable for the faculty sample (participants selected age ranges represented by values with a range of $1=$ less than 1 year to $7=20$ years or more). 
TABLE 1

STUDY 1: DESCRIPTIVE STATISTICS AND BIVARIATE CORRELATIONS FOR FACULTY

\begin{tabular}{|c|l|l|c|c|c|c|c|c|}
\hline & Variable & Mean & $S D$ & 1 & 2 & 3 & 4 & 5 \\
\hline 1. & Age & 3.86 & 1.71 & & & & & \\
\hline 2. & Gender & .67 & .47 & .09 & & & & \\
\hline 3. & Race & .13 & .34 & -.13 & .09 & & & \\
\hline 4. & Tenure & 4.98 & 2.18 & $.60 * * *$ & -.09 & -.06 & & \\
\hline 5. & Climate of respect & 5.55 & 1.06 & -.07 & .05 & .03 & $-.19 *$ & \\
\hline 6. & $\begin{array}{l}\text { Faculty extra-role } \\
\text { behaviors }\end{array}$ & 6.21 & .90 & .02 & $.21^{* *}$ & -.07 & .05 & $.29 * * *$ \\
\hline
\end{tabular}

Note: $\mathrm{N}=147$; Gender, race are dummy coded $(1=$ female, minority, respectively).

$* \mathrm{p}<.05 * * \mathrm{p}<.01 * * * \mathrm{p}<.001$

Results

The main analysis used for testing the hypothesis 1 was hierarchical multiple regression using faculty data. The sex variables were dummy coded to compare against male (female $=1$ ). Table 1 displays the means, standard deviations, correlations and reliability alphas for the study variables.

TABLE 2

STUDY 1: DESCRIPTIVE STATISTICS AND BIVARIATE CORRELATIONS FOR FACULTY

\begin{tabular}{lll}
\hline Variable & Step $1 \beta$ & Step $2 \beta$ \\
\hline Age & -.08 & -.10 \\
Gender & -.08 & -.09 \\
Race & $.23^{*}$ & $.22^{*}$ \\
Tenure & .11 & .18 \\
Climate of respect & & $.31^{* *}$ \\
$\Delta R 2$ & .02 & $.09^{* *}$ \\
$R 2$ & .02 & $.11^{* *}$ \\
\hline
\end{tabular}

Note: $\mathrm{N}=147$; Gender, Race are dummy coded $(1$ = female, minority, respectively).

$* \mathrm{p}<.05 ; * * \mathrm{p}<.01$.

Hypothesis 1 investigated if faculty climate of respect is positively related to faculty extra role behaviors from the faculty perspective. Using hierarchical multiple regression, faculty extra role behaviors was regressed on the control variables age, gender, race and ethnicity, and tenure in Step 1, and the independent variable climate of respect was entered in Step 2. Hypothesis 1 was supported with a significant main effect for climate of respect on faculty extra role behaviors $(\beta=.31 ; p<.01)$; the control variable of race and ethnicity was also found to predict climate of respect $(\beta=.22 ; p<.05)$, explaining $9 \%$ of its variance $(\Delta \mathrm{R} 2=.09, \mathrm{~F}(1,114)=11.95, \mathrm{p}<.01)$. breakdown of the results is shown in Table 2 . These results served as a benchmark to investigate the effects of student-reported climate of respect on faculty extra role behaviors and satisfaction with academic performance in Study 2 (hypotheses 2 through 4).

\section{Study 2}

Students from this private university were invited to participate in a voluntary and anonymous student online survey. In total 738 students responded to the survey. This represented a participation rate of $18.5 \%$. Respondents who answered the demographic questions identified as 70.9\% female; $26.9 \%$ male; and .17\% transgender; 38.4\% non-Hispanic White; 35.7\% Latinx/Hispanic; 14.5\% Black/African American; 3.5\% Middle Eastern; and 2.1\% Asian; 70\% were between 18-24 years old; 15.7\% were between 25-34; and 
$12.6 \%$ were older than 35 . Subjects with missing data related to the variables being investigated were not included in the statistical analysis. Since less than one percent of the student subjects identified as transgender, that one case was not included in the statistical analysis. As a result, 536 valid responses for students $(\mathrm{N}=536)$ were used.

\section{Measures}

As with Study 1, the survey questions utilized were adapted from questions and sources provided by Excelencia in Education's Latino Student Success (LSS) Inquiry Model (2014), which included surveys utilized by member institutions from which to draw questions.

Climate of Respect. As with the faculty survey, we adapted and modified questions from the surveys provided by Excelencia from various universities that were related to the diversity climate to develop the survey items. Seven items were used to measure climate of respect for identity affiliation for students yielding a coefficient $\alpha=0.92$, respectively. Sample items include: "I am treated with respect and dignity regardless of my gender," and "I am treated with respect and dignity regardless of my race or ethnicity." Students responded to all questions on a 7 -point scale $(1=$ strongly disagree to $7=$ strongly agree $)$.

Faculty Extra Role Behavior. Faculty extra role behaviors was measured with the following question: "I find that faculty is willing to put in a great deal of effort beyond what is normally expected in order for me to be successful." Students responded to this question on a 7-point scale $(1=$ strongly disagree to $7=$ strongly agree).

Students' Satisfaction With Academic Performance. Students' satisfaction with academic performance was measured with the following question: "I am satisfied with my academic performance here at this university." Students responded to this question on a 7 -point scale $(1=$ strongly disagree to $7=$ strongly agree).

Control Variables. Race and ethnicity, age and gender were entered as control variables for students consistent with prior studies on diversity (e.g., Avery, 2003; Thomas \& Wise, 1999; Walker et al., 2007; 2009).

TABLE 3

STUDY 2: DESCRIPTIVE STATISTICS AND BIVARIATE CORRELATIONS FOR STUDENTS

\begin{tabular}{|r|l|l|l|l|l|l|l|l|l|}
\hline & \multicolumn{1}{|c|}{ Variable } & Mean & SD & 1 & 2 & 3 & 4 & 5 & 6 \\
\hline 1. & Age & 1.50 & .92 & & & & & & \\
\hline 2. & Gender & .72 & .45 & -.03 & & & & & \\
\hline 3. & Race & .59 & .49 & -.03 & .06 & & & & \\
\hline 4. & Climate of respect & 5.93 & 1.00 & -.07 & $.09^{*}$ & .01 & & & \\
\hline 5. & $\begin{array}{l}\text { Faculty extra-role } \\
\text { behaviors }\end{array}$ & 5.62 & 1.39 & .04 & .01 & .02 & $.64^{* * *}$ & & \\
\hline $\begin{array}{l}\text { Satisfaction w/ } \\
\text { academic } \\
\text { performance }\end{array}$ & 5.67 & 1.41 & $.17^{* * *}$ & .04 & $-.11^{*}$ & $.27^{* * *}$ & $.36^{* * *}$ & \\
\hline
\end{tabular}

Note: $\mathrm{N}=536$; Gender, race are dummy coded ( 1 = female, minority, respectively).

${ }^{*} \mathrm{p}<.05 ; * * \mathrm{p}<.01 ; * * * \mathrm{p}<.001$

Results

After concluding that faculty climate of respect positively affects faculty extra role behaviors in Study 1, in Study 2 we confirm the relationship between climate of respect and faculty extra role behaviors and examine the degree to which these variables affect student satisfaction with their academic performance. Table 3 displays the means, standard deviations, correlations and reliability alphas for the study variables. Hypotheses 2 through 4 investigated the relationship between climate of respect, faculty extra role 
behaviors and the dependent variable satisfaction with academic performance. Hypotheses 2 and 3 were tested using hierarchical multiple regression by first entering the control variables age and gender in Step 1, entering the race and ethnicity dummy variable in step 2, climate of respect in Step 3, and faculty extra role behaviors in step 4. Hypothesis 5 investigated the two-way interaction effect between students' race and ethnicity and climate of respect on satisfaction with academic performance. The two-way interaction term between climate of respect and race and ethnicity was entered in Step 5. The overall model explained $18 \%$ of the variance in satisfaction with academic performance $(\mathrm{R} 2=.18, \mathrm{~F}(6,529)=19.39, \mathrm{p}<.001)$.

Hypothesis 4 investigated the direct and indirect effect of climate of respect on satisfaction with academic performance through faculty extra role behaviors. Using path analysis in Mplus v.8 we examined both the direct and indirect effects of the various $\mathrm{X}$ variables on the $\mathrm{Y}$ variable (Kellar \& Kelvin, 2013).

In the first step of the regression model, the control variable age $(\beta=.17 ; p<.001)$ was positively and significantly related to satisfaction with academic performance. Gender $(\beta=.04 ; p=.343)$ was not significantly related to satisfaction with academic performance. Both variables in the model together explained $3 \%$ of variance in the dependent variable $(\mathrm{R} 2=.03, \mathrm{~F}(2,533)=8.46, \mathrm{p}<.001)$. Student race and ethnicity explained an additional $1 \%$ variance in satisfaction with academic performance $(\Delta \mathrm{R} 2=.01, \mathrm{~F}(1$, $532)=6.57, \mathrm{p}<.05)$ with minority students $(\beta=-.11 ; \mathrm{p}<.05)$ having an inverse relationship to satisfaction with academic performance compared to non-Hispanic White students in the second step of the model. In the third step of the model, climate of respect was entered. Hypothesis 2, proposing that climate of respect is positively related to satisfaction with academic performance was supported $(\beta=.28 ; p<.001)$. In the fourth step, faculty extra role behaviors was added to the model and was positively related to satisfaction with academic performance $(\beta=.30 ; p<.001)$ supporting Hypothesis 3 .

The significant effect of climate of respect (Hypothesis 2) and faculty extra role behaviors (Hypothesis 3 ) on satisfaction with academic performance made it possible to examine the indirect effect of climate of respect on their satisfaction with academic performance proposed in our fourth hypothesis. The result of the path analysis indicated that climate of respect is related to faculty extra role behaviors $(\beta=.66 ; p<.001)$, thereby satisfying the Baron \& Kenny (1986) procedure to interpret mediation effects. Moreover, a part of the total effect of climate of respect on students' satisfaction with academic performance was mediated by faculty extra role behaviors $(\beta=.14 ; \mathrm{p}<.001)$. Thus, Hypothesis 4 was supported.

TABLE 4

\section{STUDY 2: HIERARCHICAL REGRESSION ANALYSES OF INTERACTION EFFECTS ON} SATISFACTION WITH ACADEMIC PERFORMANCE

\begin{tabular}{|c|c|c|c|c|c|}
\hline & \multicolumn{4}{|c|}{ Main Effects } & $\begin{array}{l}\text { Two-way } \\
\text { Interactions }\end{array}$ \\
\hline Variable & Step $1 \beta$ & Step $2 \beta$ & Step $3 \beta$ & Step $4 \beta$ & Step $5 \beta$ \\
\hline Age & $.17 * * *$ & $.17 * * *$ & $.19 * * *$ & $.16 * * *$ & $.17 * * *$ \\
\hline Gender & .04 & .05 & .02 & .04 & .04 \\
\hline Race & & $-.11 *$ & $-.11 * *$ & $-.12 * *$ & $-.12 * *$ \\
\hline Climate of respect & & & $.28 * * *$ & .08 & -.03 \\
\hline $\begin{array}{l}\text { Faculty extra-role } \\
\text { behaviors }\end{array}$ & & & & $.30 * * *$ & $.31 * * *$ \\
\hline Race $\times$ Climate of Respect & & & & & $.14 *$ \\
\hline$\Delta R 2$ & $.03 * * *$ & $.01 *$ & $.13 * * *$ & .00 & $.01 *$ \\
\hline$R 2$ & .03 & .04 & .17 & .17 & .18 \\
\hline
\end{tabular}

Note: $\mathrm{N}=536$; Gender, Race are dummy coded ( 1 = female, minority, respectively).

${ }^{*} \mathrm{p}<.05 ; * * \mathrm{p}<.01 ; * * * \mathrm{p}<.001$

Hypothesis 5 examined the moderating effect of race and ethnicity on the relationship between climate of respect and satisfaction with their academic performance. The race $\times$ climate of respect interaction effect on satisfaction with academic performance was significant $(\beta=.14 ; \mathrm{p}<.05)$ supporting our fifth hypothesis. 
A breakdown of the significance of the two-way interaction effect between race and ethnicity and climate of respect on satisfaction with academic performance is shown in Table 4. Overall, the effect of climate of respect on satisfaction with their academic performance is greater for minority students than non-Hispanic White students. Moreover, as depicted in the graph of the interaction in Figure 1, race and ethnicity influences the effect of climate of respect on satisfaction with academic performance such that the satisfaction with academic performance increases for minority students compared to non-Hispanic White students as climate of respect strengthens. Interestingly, the graph of the two-way interaction suggests that when the climate of respect is strong, satisfaction with academic performance increases for minority students (from $\mathrm{M}=6.13$ to $\mathrm{M}=6.57$ ) with simple slope tests demonstrating that the difference is significant $(\mathrm{t}=2.47, \mathrm{p}<.05)$. However, it appears from the graph of the two-way interaction that satisfaction with academic performance slightly decreases for non-Hispanic White students (from $\mathrm{M}=5.19$ to $\mathrm{M}=5.11$ ) when the climate of respect is strong, although the slope test revealed the difference was not significant $(\mathrm{t}$ $=-.37, \mathrm{p}=.71)$.

FIGURE 1

\section{TWO-WAY INTERACTION EFFECT BETWEEN CLIMATE OF RESPECT AND RACE \& ETHNICITY ON SATISFACTION WITH ACADEMIC PERFORMANCE}

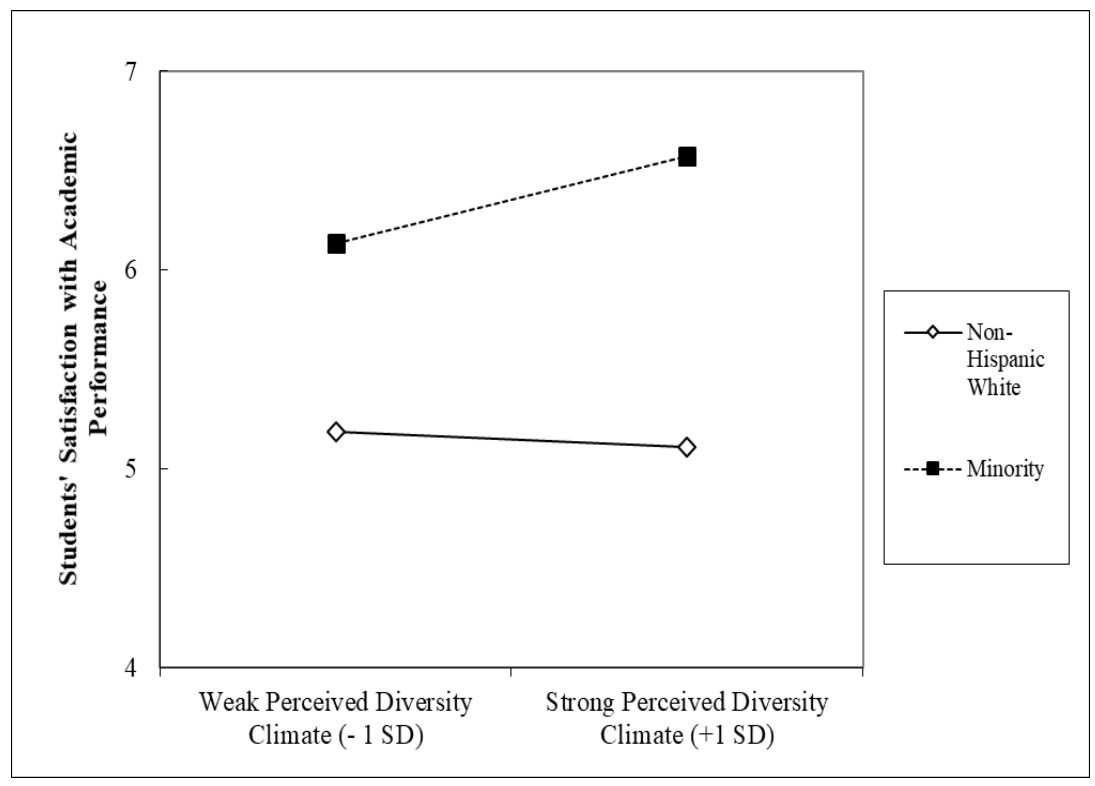

\section{DISCUSSION}

In this study, we contribute to the diversity climate literature, particularly in higher education. While prior research has mostly focused on the effect that diversity climate has on students, we advance the literature by investigating if climate of respect affects the behavior of faculty, specifically their extra role behaviors. We know from prior research that the role faculty play in the success of students is significant (Astin, 1993; Campbell \& Campbell, 1997; Gandara, 1995; Pascarella \& Terenzini, 1976; Rendon, 1994; Spady, 1971). Our results demonstrate that the effect of both faculty and students' perceptions of climate of respect and faculty extra role behaviors on student outcomes are not only significant but connected. The findings suggest that the extra role behaviors that students observe, and experience of faculty may indeed be influenced by the faculty perceptions of climate of respect, as perceptions of diversity climate was significantly related to faculty extra role behaviors. In turn, students' perceptions of both faculty extra role behaviors and diversity climate affected their satisfaction with their academic performance. In addition, consistent with previous findings (e.g., Cabrera et al., 1999; Hurtado et al., 1998; Museus et al., 2008; Nora 
\& Cabrera, 1996; Reid \& Radhakrishnan, 2003), our results suggest that students' perceptions and reactions to diversity climate differ by race and ethnicity. We found that in this institution, the relationship between students' climate of respect and satisfaction with academic performance was stronger for minority students than for non-Hispanic White students.

\section{Theoretical Implications}

As proposed in our first hypothesis, our findings indicate that the stronger the climate of respect by faculty, the greater their extra role behavior. This finding supports research in the management literature regarding how perceptions of diversity and inclusion influence the behavior of employees (e.g., Chung et al., 2015; Singh \& Selvarajan, 2013). In line with insights from social identity theory and workplace diversity research, our results suggest that faculty are similar to employees in traditional organizations and are affected by perceptions of diversity and inclusion in the same way. In support of our second hypothesis, the results show that students report higher satisfaction with their academic performance when they perceive the climate as one that respects and values diversity. Interestingly, we also found that student reported faculty extra role behaviors is positively related to their satisfaction with academic performance supporting the third hypothesis. This result is striking because it suggests a link, albeit indirectly, between faculty perceptions of climate of respect and students' satisfaction with their academic performance. Specifically, our results indicate that when faculty perceive a positive climate of respect, that it motivates them to go above and beyond their prescribed role, and when students perceive that faculty go above and beyond, that leads to higher students' satisfaction with their academic performance. We contend this is reasonable to assume because of the positive relationship between faculty-reported climate of respect and faculty-reported faculty extra role behaviors, and the positive relationship between student-reported faculty extra role behaviors and student satisfaction with their academic performance. Although it is empirically clear that student climate of respect and their reported faculty extra role behaviors affects their satisfaction with academic performance, an assumption can also be made that perceptions climate of respect and faculty extra role behaviors reported by faculty participants indirectly impact student satisfaction with their academic performance. Compared to prior research that mainly focuses on the impact that diversity has on students, our findings underscore the equally important need to understand how the diversity climate affects faculty and ultimately student outcomes.

Results from Hypothesis 4 point to an underlying mechanism that links the effect of climate of respect to students' satisfaction with academic performance. Climate of respect not only relates directly to students' satisfaction with their academic performance, but also through their perceptions regarding faculty extra role behaviors. Moreover, our study emphasizes the driving force of students' perceptions of faculty extra role behaviors on students' satisfaction with academic performance, especially when it is influenced by a climate viewed by both its students and faculty to value diversity.

Supporting our fifth hypothesis, indeed race and ethnicity moderated the effect of the diversity climate on students' satisfaction with academic performance. Consistent with results from previous studies, the main effect for race on satisfaction with academic performance suggests that minority students were less satisfied with their academic performance than non-Hispanic White students. Another important key finding is that non-Hispanic White and minority students were satisfied with their academic performance differently when climate of respect was perceived to be strong. Specifically, minority students reported significantly higher satisfaction with academic performance when climate of respect was perceived to be strong compared to when it was weak. Based on the results, we contend that for minority students, it is very important for climate of respect to be strong to be impactful on student outcomes.

Interestingly, though not significant, satisfaction with academic performance decreased for nonHispanic White students when diversity climate was strong. Our results underscore the complexity of race and ethnicity on the campus experience of students, and the importance of gaining a better understanding of why these differences in attitudes towards climate of respect and student satisfaction with academic performance exist between different racial identity groups in institutions of higher education. For example, it is possible that non-Hispanic White students might view diversity initiatives less favorably indicating the potential for diversity initiatives in higher education to backfire among non-Hispanic White students if not 
managed or implemented well. This is similar to instances in organizations where lower organizational attachment occurs for White group members when work groups become more heterogeneous (Tsui et al., 1992) or employee backlash occurs from majority group members when diversity training is introduced (Bezrukova et al., 2012). Future studies should explore this line of research further within the context of higher education.

\section{Practical Implications}

Our results explain some important findings related to the effect the diversity climate has on student outcomes. First, the results suggest that the way that the climate of respect affects institutions of higher learning is indeed complex and multi-faceted. The results indicate that both faculty extra role behaviors and climate contribute to how students feel about their academic performance. Moreover, not only does ensuring a climate of respect influence faculty extra role behaviors for faculty, climate of respect impacts how students perceive extra role behaviors and ultimately satisfaction with their academic performance. Thus, climate of respect has a dual effect. In other words, a climate of respect influences different targets, i.e. faculty, students, and possibly staff, in different ways. The way in which the university climate is perceived is important to stakeholders beyond students, and faculty should be a larger part of the conversation regarding the culture of diversity in academic settings. Drawing from the human resources and workplace diversity literature, it is evident that the diversity climate has similar effects on faculty as employees. Viewing the higher education institution as an organization, and faculty and staff as employees may serve as a beneficial paradigm shift to better understand the importance of investing in diversity initiatives aimed at supporting female and minority faculty which will in turn contribute toward improving student outcomes. Furthermore, the results support research that students from different racial backgrounds are affected by diversity and experience it in their academic life differently and not in the same way. Institutions of higher education should consider these findings when creating diversity initiatives because they suggest that the attitudes and beliefs of students vary between and among racial identity groups and should not be viewed as monolithic.

\section{Limitation and Future Research}

The study was conducted in one institution limiting its generalizability. For future research, the study should be conducted across multiple university types to investigate differences between private, public, Hispanic Serving Institutions (HSIs), Historically Black Universities and Colleges (HBCUs), and Predominantly White Institutions (PWIs). The current study used self-report measures, it would be valuable to conduct research on faculty extra role behaviors using dyads for climate and faculty extra role behaviors. This would also allow for investigating the role of race and ethnicity and gender of faculty, as well as students, simultaneously. Although subjects were informed that their responses would be anonymous and remain confidential, social desirability and mono-method bias as a result of common method variance may have affected the results of the data (Spector, 1994).

Because minority racial groups should not be assumed to share similar beliefs, future research should expand the scope of this study by investigating intragroup racial minority differences in how perceived diversity climate and faculty extra role behaviors and caring may be interpreted. Also, further exploration is needed to investigate gender differences in how climate of respect and faculty extra role behaviors affect student satisfaction with academic performance and if intersectionality between race and gender plays a role in forming students' perceptions.

Data for the current study were primarily collected using survey data collection methods. Future researchers should develop more qualitative methods such as interviews to collect richer data from faculty and students that may explain the circumstances under which students perceive their university's climate to be diverse, faculty to be more caring, and how those factors interact with race to influence satisfaction with academic performance. More research is needed in this area to identify how and why a university's climate of diversity affects some students different from others.

Given prior research that provides evidence that a university's diversity climate affects student outcomes, implications of the current study may further the understanding for higher education 
administrators, researchers, and faculty regarding what environmental factors play a role in not only student outcomes, but also outcomes for faculty which indirectly affect students. An implication of these findings is that the diversity climate is equally important for both faculty and students. Additionally, decision makers in higher education should consider how diversity initiatives may impact both minority and non-Hispanic White students to ensure their strategy is implemented in a way that does not backfire. Creating an environment that supports faculty diversity is critical, as it is clear that the diversity climate affects faculty extra role behaviors which in turn contributes to student satisfaction with academic performance leading to graduation and retention.

\section{CONCLUSION}

The purpose of this study was to examine how climate of respect affects faculty extra role behaviors and, how faculty extra role behaviors and climate of respect affect satisfaction with academic performance. Further, we examined the moderating effect of race on the relationship between climate of respect and satisfaction with academic performance. The results demonstrate that 1) the climate of respect among faculty is positively related to their faculty extra role behaviors; 2) that climate of respect affects satisfaction with academic performance directly and indirectly via faculty extra role behaviors, and 3) that race strengthens the effect of climate of respect on satisfaction with academic performance. Specifically, race moderates this relationship as minority students reported greater satisfaction with academic performance in a strong diverse climate. Overall, a climate of diversity may not be effective by itself at impacting how students feel about their academic performance, and that faculty extra role behaviors plays a necessary role in influencing the effect that a diversity climate has on student outcomes. Therefore, leaders in higher education should pay greater attention to addressing diversity issues for faculty, as well as for students, in order to impact their motivation to go above and beyond for their students. However, institutions must also be mindful to balance the way in which they manage diversity initiatives needed to positively affect all students.

\section{REFERENCES}

Alderfer, C.P. (1987). An intergroup perspective on organizational behavior. Handbook of Organizational Behavior, pp. 190-222.

Astin, A.W. (1993). What matters in college? Four critical years revisited. Jossey-Bass. Inc., Publishers: San Francisco.

Avery, D.R. (2003). Reactions to diversity in recruitment advertising--are differences black and white? Journal of Applied Psychology, 88(4), 672-679.

Baron, R.M., \& Kenny, D.A. (1986). The moderator-mediator variable distinction in social psychological research: Conceptual, strategic, and statistical considerations. Journal of Personality and Social Psychology, 51(6), 1173-1182.

Baturay, M.H. (2011). Relationships among sense of classroom community, perceived cognitive learning and satisfaction of students at an e-learning course. Interactive Learning Environments, 19(5), 563-575.

Bennett, A.K., Tillman-Kelly, D.L., Shuck, J.R., Viera, J.M., \& Wall, B.J. (2011). Narratives of Black and Latino faculty at a midwestern research university. Journal of the Student Personnel Association at Indiana University, pp. 46-61.

Bennett, C., \& Okinaka, A.M. (1990). Factors related to persistence among Asian, Black, Hispanic, and White undergraduates at a predominantly White university: Comparison between first and fourth year cohorts. The Urban Review, 22(1), 33-60.

Bezrukova, K., Jehn, K.A., \& Spell, C.S. (2012). Reviewing diversity training: Where we have been and where we should go. Academy of Management Learning \& Education, 11(2), 207-227.

Blank, R., \& Slipp, S. (1994). The white male: An endangered species? Management Review, 83(9), 2732. 
Bowman, N.A., \& Denson, N. (2014). A missing piece of the departure puzzle: Student-institution fit and intent to persist. Research in Higher Education, 55(2), 123-142.

Brown, J.D., Cober, R.T., Keeping, L.M., \& Levy, P.E. (2006). Racial tolerance and reactions to diversity information in job advertisements. Journal of Applied Social Psychology, 36(8), 2048-2071.

Cabrera, A.F., \& Nora, A. (1994). College students' perceptions of prejudice and discrimination and their feelings of alienation: A construct validation approach. The Review of Education/ Pedagogy/ Cultural Studies, 16(3-4), 387-409.

Cabrera, A.F., Nora, A., Terenzini, P.T., Pascarella, E., \& Hagedorn, L.S. (1999). Campus racial climate and the adjustment of students to college: A comparison between White students and AfricanAmerican students. The Journal of Higher Education, 70(2), 134-160.

Campbell, T.A., \& Campbell, D.E. (1997). Faculty/student mentor program: Effects on academic performance and retention. Research in Higher Education, 38(6), 727-742.

Chung, Y., Liao, H., Jackson, S.E., Subramony, M., Colakoglu, S., \& Jiang, Y. (2015). Cracking but not breaking: Joint effects of faultline strength and diversity climate on loyal behavior. Academy of Management Journal, 58(5), 1495-1515.

Cole, M.T., Shelley, D.J., \& Swartz, L.B. (2014). Online instruction, e-learning, and student satisfaction: A three year study. The International Review of Research in Open and Distributed Learning, 15(6), 111-131.

Cox, T. (1994). Cultural diversity in organizations: Theory, research and practice. Berrett-Koehler Publishers.

de Brey, C., Musu, L., McFarland, J., Wilkinson-Flicker, S., Diliberti, M., Zhang, A., .. Wang, X. (2019). Status and trends in the education of racial and ethnic groups 2018 (NCES 2019-039). U.S. Department of Education. Washington, D.C.: National Center for Education Statistics. Retrieved from https://nces.ed.gov/pubsearch

DiPaola, M., \& Tschannen-Moran, M. (2001). Organizational citizenship behavior in schools and its relationship to school climate. Journal of School Leadership, 11(5), 424-447.

DiPaola, M.F., \& Hoy, W.K. (2005). Organizational citizenship of faculty and achievement of high school students. The High School Journal, 88(3), 35-44.

Erum, H., Abid, G., Contreras, F., \& Islam, T. (2020). Role of family motivation, workplace civility and self-efficacy in developing affective commitment and organizational citizenship behavior. European Journal of Investigation in Health, Psychology and Education, 10(1), 358-374.

Excelencia in Education. (2014). Latino Student Success (LSS) Inquiry Model. Retrieved from https://www.edexcelencia.org/programs-latino-student-success

Excelencia in Education. (2016). Retrieved from https://www.edexcelencia.org/research/hispanic-servinginstitutions-hsis

Fischer, E.M.J. (2007). Settling into campus life: Differences by race/ethnicity in college involvement and outcomes. The Journal of Higher Education, 78(2), 125-161.

Foster, C., \& Harris., L. (2005). Easy to say, difficult to do: Diversity management in retail. Human Resource Management Journal, 15(3), 4-17.

Fry, R., \& Cilluffo, A. (2019). A rising share of undergraduates are from poor families, especially at less selective colleges. Pew Research Center.

Gandara, P. (1995). Over the Ivy Walls: The Educational Mobility of Low-Income Chicanos. SUNY Series, Social Context of Education.

George, J.M., \& Jones, G.R. (1997). Organizational spontaneity in context. Human Performance, 10(2), $153-170$.

Goldman, B.M., Gutek, B.A., Stein, J.H., \& Lewis, K. (2006). Employment discrimination in organizations: Antecedents and consequences. Journal of Management, 32(6), 786-830.

Gonzalez, J.A., \& Denisi, A.S. (2009). Cross-level effects of demography and diversity climate on organizational attachment and firm effectiveness. Journal of Organizational Behavior: The International Journal of Industrial, Occupational and Organizational Psychology and Behavior, $30(1), 21-40$. 
Harper, S.R., \& Hurtado, S. (2007). Nine themes in campus racial climates and implications for institutional transformation. New Directions for Student Services, 120, 7-24.

Hicks-Clarke, D., \& Iles, P. (2000). Climate for diversity and its effects on career and organisational attitudes and perceptions. Personnel Review, 29(3), 324-346.

Hurtado, S., \& Alvarado, A.R. (2012). The climate for underrepresented groups and diversity on campus. American Academy of Political and Social Science, 634(1), 190-206.

Hurtado, S., \& Carter, D.F. (1997). Effects of college transition and perceptions of the campus racial climate on Latino college students' sense of belonging. Sociology of Education, 70(4), 324-345.

Hurtado, S., Alvarado, A.R., \& Guillermo-Wann, D. (2015). Thinking about race: The salience of racial identity at two-and four-year colleges and the climate for diversity. The Journal of Higher Education, 86(1), 127-155.

Hurtado, S., Alvarez, C.L., Guillermo-Wann, C., Cuellar, M., \& Arellano, L. (2012). A model for diverse learning environments. In Higher Education: Handbook of Theory and Research (pp. 41-122). Springer, Dordrecht.

Hurtado, S., Carter, D.F., \& Spuler, A. (1996). Latino student transition to college: Assessing difficulties and factors in successful college adjustment. Research in Higher Education, 37(2), 135-157.

Hurtado, S., Clayton-Pedersen, A.R., Allen, W.R., \& Milem, J.F. (1998). Enhancing campus climates for racial/ethnic diversity: Educational policy and practice. The Review of Higher Education, 21(3), 279-302.

Jimmieson, N.L., Hannam, R.L., \& Yeo, G.B. (2010). Teacher organizational citizenship behaviours and job efficacy: Implications for student quality of school life. British Journal of Psychology, 101(3), 453-479.

Joshi, A., Liao, H., \& Jackson, S.E. (2006). Cross-level effects of workplace diversity on sales performance and pay. Academy of Management Journal, 49(3), 459-481.

Katz, D. (1964). The motivational basis of organizational behavior. Behavioral Science, 9(2), 131-146.

Kearney, E., \& Gebert, D. (2009). Managing diversity and enhancing team outcomes: The promise of transformational leadership. Journal of Applied Psychology, 94(1), 77-89.

Kellar, S.P., \& Kelvin, E.A. (2013). Munro's statistical methods for health care research. Wolters Kluwer Health/Lippincott Williams \& Wilkins.

Kim, Y.L., \& Lee, S.M. (2015). Effect of satisfaction in major at university on academic achievement among physical therapy students. Journal of Physical Therapy Science, 27(2), 405-409.

Köllen, T. (2016). Lessening the difference is more-the relationship between diversity management and the perceived organizational climate for gay men and lesbians. The International Journal of Human Resource Management, 27(17), 1967-1996.

Kossek, E.E., \& Zonia, S.C. (1993). Assessing diversity climate: A field study of reactions to employer efforts to promote diversity. Journal of Organizational Behavior, 14(1), 61-81.

Kundu, S.C., \& Mor, A. (2016). Effect of diversity management on employees' organisational commitment: A study of Indian organisations. Journal of Strategic Human Resource Management, 5(1), 16-22.

Lambert, J.R. (2015). The impact of gay-friendly recruitment statements and due process employment on a firm's attractiveness as an employer. Equality, Diversity and Inclusion: An International Journal, 34(6), 510-526.

Lamport, M.A. (1993). Student-faculty informal interaction and the effect on college student outcomes: A review of the literature. Adolescence, 28(112), 971.

Lauring, J., \& Selmer, J. (2011). Multicultural organizations: Does a positive diversity climate promote performance? European Management Review, 8(2), 81-93.

LePine, J., Hanson, M.A., Borman, W.C., \& Motowidlo, S.J. (2000). Contextual performance and teamwork: Implications for staffing. Research in Personnel and Human Resources Management, pp. 53-90. 
LePine, J.A., Erez, A., \& Johnson, D.E. (2002). The nature and dimensionality of organizational citizenship behavior: A critical review and meta-analysis. Journal of Applied Psychology, 87(1), 52.

Lin, S., Salazar, T.R., \& Wu, S. (2019). Impact of academic experience and school climate of diversity on student satisfaction. Learning Environments Research, 22(1), 25-41.

Locks, A.M., Hurtado, S., Bowman, N.A., \& Oseguera, L. (2008). Extending notions of campus climate and diversity to students' transition to college. The Review of Higher Education, 31(3), 257-285.

Loo, C.M., \& Rolison, G. (1986). Alienation of ethnic minority students at a predominantly White university. The Journal of Higher Education, 57(1), 58-77.

McKay, P.F., Avery, D.R., \& Morris, M.A. (2008). Mean racial-ethnic differences in employee sales performance: The moderating role of diversity climate. Personnel Psychology, 61(2), 349-374.

McKay, P.F., Avery, D.R., Liao, H., \& Morris, M.A. (2011). Does diversity climate lead to customer satisfaction? It depends on the service climate and business unit demography. Organization Science, 22(3), 788-803.

McKay, P.F., Avery, D.R., Tonidandel, A., Morris, M.A., Hernandez, M., \& Hebl, M.R. (2007). Racial differences in employee retention: Are diversity climate perceptions the key? Personnel Psychology, 60(1), 35-62.

Milem, J.F. (2001). Increasing Diversity Benefits: How Campus Climate and Teaching Methods Affect Student Outcomes.

Moeller, M., Harvey, M., \& Williams, W. (2010). Socialization of inpatriate managers to the headquarters of global organizations: A social learning perspective. Human Resource Development Review, 9(2), 169-193.

Moon, K. (2016). The effects of diversity and transformational leadership climate on organizational citizenship behavior in the US federal government: An organizational-level longitudinal study. Public Performance \& Management Review, 40(2), 361-381.

Mor Barak, M.E., Cherin, D.A., \& Berkman, S. (1998). Organizational and personal dimensions in diversity climate: Ethnic and gender differences in employee perceptions. The Journal of Applied Behavioral Science, 34(1), 82-104.

Museus, S.D., Nichols, A.H., \& Lambert, A.D. (2008). Racial differences in the effects of campus racial climate on degree completion: A structural equation model. The Review of Higher Education, 32, 107-134.

Nguyen, M.H., Chan, J., Nguyen, B.M.D., \& Teranishi, R.T. (2018). Beyond compositional diversity: Examining the campus climate experiences of Asian American and Pacific Islander students. Journal of Diversity in Higher Education, 11(4), 484.

Nishii, L.H. (2013). The benefits of climate for inclusion for gender-diverse groups. Academy of Management Journal, 56(6), 1754-1774.

Nora, A., \& Cabrera, A.F. (1996). The role of perceptions of prejudice and discrimination on the adjustment of minority students to college. The Journal of Higher Education, 67(2), 119-148.

Pascarella, E.T., \& Terenzini, P.T. (1976). Informal interaction with faculty and freshman ratings of academic and non-academic experience of college 1. The Journal of Educational Research, $70(1), 35-41$.

Perkins, L.A., Thomas, K.M., \& Taylor, G.A. (2000). Advertising and recruitment: Marketing to minorities. Psychology \& Marketing, 17(3), 235-255.

Piercy, F., Giddings, V., Allen, K.A., Dixon, B., Meszaros, P., \& Joest, K. (2005). Improving campus climate to support faculty diversity and retention: A pilot program for new faculty. Innovative Higher Education, 30(1), 53-66.

Podsakoff, N.P., Whiting, S.W., Podsakoff, P.M., \& Blume, B.D. (2009). Individual-and organizationallevel consequences of organizational citizenship behaviors: A meta-analysis. Journal of Applied Psychology, 94(1), 122-141. 
Podsakoff, P.M., MacKenzie, S.B., Paine, J.B., \& Bachrach, D.G. (2000). Organizational citizenship behaviors: A critical review of the theoretical and empirical literature and suggestions for future research. Journal of Management, 26(3), 513-563.

Portolese Dias, L., \& Trumpy, R. (2014). Online Instructor's Use of Audio Feedback to Increase Social Presence and Student Satisfaction. Journal of Educators Online, 11(2).

Pugh, S.D., Dietz, J., Brief, A.P., \& Wiley, J.W. (2008). Looking inside and out: The impact of employee and community demographic composition on organizational diversity climate. Journal of Applied Psychology, 93(6), 1422-1428.

Reichers, A.E., \& Hudy, M.J. (1997). Overall Job Satisfaction: How Good Are Single-Item Measures? Journal of Applied Psychology, 82(2), 247-252.

Reid, L.D., \& Radhakrishnan, P. (2003). Race matters: The relation between race and general campus climate. Cultural Diversity and Ethnic Minority Psychology, 9(3), 263-275.

Rendon, L.I. (1994). Validating culturally diverse students: Toward a new model of learning and student development. Innovative Higher Education, 19(1), 33-51.

Roberson, L., \& Block, C.J. (2001). Racioethnicity and job performance: A review and critique of theoretical perspectives on the causes of group differences. Research in Organizational Behavior, 23, 247-325.

Robotham, K., \& Cortina, L. (2019). Promoting respect as a solution to workplace harassment. Equality, Diversity and Inclusion: An International Journal, 40(4), 410-429.

Sacco, J.M., \& Schmitt, N. (2005). A dynamic multilevel model of demographic diversity and misfit effects. Journal of Applied Psychology, 90(2), 203-231.

Schachner, M.K., Schwarzenthal, M., van de Vijver, F., Jr., \& Noack, P. (2019). How all students can belong and achieve: Effects of the cultural diversity climate amongst students of immigrant and nonimmigrant background in Germany. Journal of Educational Psychology, 111(4), 703-716.

Shakurnia, A., Alijani, H., Najjar, S., \& Elhampour, H. (2014). Correlation between educational satisfaction and approaches to study and academic performance a study of nursing and midwifery students. Iranian Journal of Medical Education, 14(2), 101-109.

Singh, B., \& Selvarajan, T.T. (2013). Is it spillover or compensation? Effects of community and organizational diversity climates on race differentiated employee intent to stay. Journal of Business Ethics, 115(2), 259-269.

Singh, B., Winkel, D.E., \& Selvarajan, T.T. (2013). Managing diversity at work: Does psychological safety hold the key to racial differences in employee performance? Journal of Occupational and Organizational Psychology, 86(2), 242-263.

Spady, W.G. (1971). Dropouts from higher education: Toward an empirical model. Interchange, 2(3), 3862.

Spector, P.E. (1994). Using self-report questionnaires in OB research: A comment on the use of a controversial method. Journal of Organizational Behavior, pp. 385-392.

Stryker, S. (1968). Identity salience and role performance: The relevance of symbolic interaction theory for family research. Journal of Marriage and the Family, pp. 558-564.

Tajfel, H., \& Turner, J.C. (1986). The social identity theory of intergroup behavior. Psychology of Intergroup Relations, 2, 7-24.

Thomas, K.M., \& Wise, G.P. (1999). Organizational attractiveness and individual differences: Are diverse applicants attracted by different factors? Journal of Business and Psychology, 13(3), 375390.

Triana, M.C., Jayasinghe, M., \& Pieper, J.R. (2015). Perceived workplace racial discrimination and its correlates: A meta-analysis. Journal of Organizational Behavior, 36(4), 491-513.

Tsui, A.S., Egan, T.D., \& O'Reilly, C.A. (1992). Being different: Relational demography and turnover in top management groups. Administrative Science Quarterly, 37(4), 549-79.

Van Dyne, L., \& LePine, J.A. (1998). Helping and voice extra-role behaviors: Evidence of construct and predictive validity. Academy of Management Journal, 4l(1), 108-119. 
Van Quaquebeke, N., Zenker, S., \& Eckloff, T. (2009). Find out how much it means to me! The importance of interpersonal respect in work values compared to perceived organizational practices. Journal of Business Ethics, 89(3), 423-431.

Walker, H.J., Field, H.S., Giles, W.F., Armenakis, A.A., \& Bernerth, J.B. (2009). Displaying employee testimonials on recruitment web sites: Effects of communication media, employee race, and job seeker race on organizational attraction and information credibility. Journal of Applied Psychology, 94(5), 1354-1364.

Wrench, J. (2005). Diversity management can be bad for you. Race \& Class, 46(3), 73-84. 